\title{
Filme de Amor: quase-cinema; quase vídeo
}

\author{
Cláudio da Costa
}

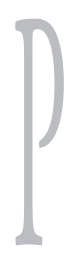

or volta do início dos anos 70, Allain Kaprow teria batido o martelo em relação à tradição da pintura ao falar sobre Pollock: "Ele realizou pinturas magníficas. Mas também destruiu a pintura”. Kaprow diria que o espectador de Pollock precisava ser um acrobata, "oscilando entre uma identificação com o corpo e as mãos que lançavam a tinta e estavam dentro da tela, e uma submissão às marcas objetivas, deixando-se envolver e assaltar por elas". O espectador, esse que faz parte do mundo externo à pintura, entrava na tela para experimenta-la, participava com seu próprio corpo no interior do quadro. Assim resumia, Kaprow: "O artista, o espectador, e o mundo exterior, interrelacionam-se plenamente aqui". As bordas do quadro que determinavam os limites entre o mundo do artista e o mundo do espectador haviam sido ultrapassadas. A essa modalidade estranha de pintura que Pollock havia iniciado com suas "quase-pinturas" provocava uma revolução que tinha duas alternativas aos jovens artistas: ou continuar no caminho das quase pinturas ou deixar totalmente de pintar (Kaprow, 1999, p. 124-31).

Nos anos 70, começava-se a descobrir que as exigências do meio são tão necessárias à arte como a expansão para fora dos seus limites. Os artistas já não mais se interessavam pelas idéias de Greenberg relativas à especificidade dos meios e dos sentidos a eles ligados. Buscavam, ao contrário, expandir o meio. O próprio Kaprow em uma entrevista a Jeanne Siegel explica como chegou ao happening. Ele diz que um desenvolvimento simples se deu na passagem da colagem à imensa assemblage que se adensava e crescia a ponto de preencher toda uma sala. Então as pessoas tinham que se mover para experimentar aquilo a que já não se podia mais chamar de objeto. Com isso, Kaprow perceberia que o observador se tornava um componente da obra, sabendo ou não. Trabalhando com mais flexibilidade os componentes, Kaprow buscava cada vez mais imprimir maior atividade participativa ao observador (Siegel, 1992, p. 167).

No Brasil, Os bichos de Lygia Clark provocaram a reflexão do não-objeto e uma inflexão na noção mesma de obra de arte: a partir desses trabalhos o espectador deixaria seu lugar de mero observador-contemplador e se tornaria um observador-participador. Por outro lado, a obra passaria a perder seu status de objeto estético a ser contemplado. Hélio Oiticica produziria

Cláudio da Costa é professor do Instituto de Artes da Universidade Estadual do Rio de Janeiro (UERJ) e coordenador do Curso de Cinema da Universidade Estácio de Sá. 
os textos que teorizariam e nomeariam esse novo espectador, definindo-o como aquele que entra no interior das obras e que agora se tornariam ambientes (Tropicália e Ninhos). Em 1973, Hélio Oiticica inaugurava um conceito que muito se assemelhava àquele de Kaprow, mas que dizia respeito às suas experiências com os ambientes audiovisuais que começava criar, como Neyrótica e os Quase cinema, Block-experiments in Cosmococa. Oiticica tentava dissolver a importância da narração ao mesmo tempo que problematizava a imagem como signo de alguma coisa que existe antes dela, sua referência. Composto de 80 slides com marcação de tempo e trilha sonora, Neyrótica, o primeiro desses trabalhos de criação audiovisual, prévia das séries Cosmococas, produz experiências-limite na disjunção entre imagem e som, mas fundamentalmente, na relação do espectador com a obra.

"Não narração é não discurso
Não fotografia "artística"
Não 'audiovisual': trilha de som
É continuidade pontuada de
interferência gravada do rádio q é
juntada à sequiência projetada de slides
de modo acidental e não como
sublinhamento da mesma
- é play-invenção" (Canongia, 1981, p. 22-3).

$\mathrm{O}$ que Oiticica sugeria com esses ambientes é que o cinema, o campo da imagem-movimento, já não poderia mais sobreviver seguindo a tradição das técnicas narrativas que privilegiam o entrecho, uma situação e uma ação que a modifique. Nessa tradição, o espectador existia num mundo externo ao mundo da obra, com o qual ele se mantinha distanciado para poder ver. Então "ver" era manter-se à distância. Era preciso que o cinema descobrisse novas formas do ver.

Era preciso mudar a recepção do cinema e o modo de ver. A experiência coletiva de espectadores sentados com seus olhares direcionados a uma imagem em movimento distanciada, projetada por um único projetor, separada do espaço real do espectador, já não mais interessava ao nosso mundo. A imagem deixa de ser aquilo que remete a algo existente anteriormente e fora dela. Entre o mundo da imagem e o mundo real - espaço de quem a olha - não há mais esse limite tão claro, pois o imaginário e o real são instâncias em constante troca. A imagem não é, portanto, aquilo a que se pode ver mantendo-se uma certa distância. A imagem é algo que produz em si mesma uma diferença radical. Nela reina a oscilação e a incerteza. A imagem, assim entendida, exigirá outra atitude do espectador, não mais mera contemplação, mas antes participação em sua própria flutuação. O participador é aquele que pratica o movimento oscilatório da imagem na imagem e não mais pode se ver distante, distanciado e protegido daquele espaço flutuante e incerto.

Nas Cosmococcas, várias imagens projetadas e uma trilha sonora com interferências de rádio e barulhos diversos produziam um distanciamento interno à própria imagem, primeiro entre o som e a imagem, mas também no interior de cada um desses meios. $\mathrm{O}$ espectador no centro dessas projeções devia não somente escolher para onde olhar, ou o que ouvir, mas inventar sentidos para as imagens e sons ainda que deslizantes e escorregadios. Participar não era mover-ser no interior do ambiente, mas deixar-se ser movido pelo movimento oscilatório da imagem e, então, inventar-se outro ao experimentar o sentido sempre flutuante da imagem. Essa era a base do conceito de quase-cinema de Oiticica.

Esses novos territórios que Oiticica inventava e que ultrapassavam os limites do cinema precisariam de um novo nome. Começaram sendo chamados de arte ambiente, ambientes audiovisuais e hoje são mais conhecidos como instalações. Os ambientes mostraram que a imagem-movimento não necessita da tela e da projeção única como suporte. Ela pode aparecer de vários modos, ainda mais hoje com as novas tecnologias digitais e do vídeo. Mas na época em que Oiticica estava inventado esses ambientes expandidos, o cinema no Rio de Janeiro ampliava seus limites, mesmo que dentro do 
campo do "cinema", com todo seu aparato que incluía a sala escura e os espectadores voltados para uma tela única. Os cineastas Júlio Bressane e Rogério Sganzerla, ainda que mantendo-se no interior do território "cinema", ultrapassavam seus limites. Essa experiência cinematográfica é que deveria ser chamada de quase-cinema. Como dizia Kaprow em relação à pintura, esses cineastas traziam o espectador para dentro da tela, tornando indiscerníveis o mundo do artista e o mundo do espectador, cada um invadindo o território do outro. Esse cinema já não é cinema, mas ainda não é outra coisa, como uma instalação. Ele só pode ser entendido como o quase-cinema que muitos artistas dos anos 70 tentaram produzir (Canongia, 1981). Esse cinema já não mais se pergunta o que é o cinema, pois ultrapassa o limite do cinema sendo, paradoxalmente, ainda cinema.

A expansão dos territórios levaria o cinema contemporâneo brasileiro a descobrir o problema da arte. Na época do Cinema Marginal a imagem-oscilação marcaria aquela produção. ${ }^{1}$ A oscilação impedia que o espectador identificasse o que via, impossibilitando a significação da imagem. Os sentidos se multiplicavam e flutuavam em contínua mudança, impedindo que o espectador se reconhecesse - como identidade, sujeito, atividade - naquele mundo em devir. Já naqueles anos o cinema ensinava o espectador que a participação dele era fundamental na invenção da obra. Inventar, porém, não seria mais produzir algo novo, negando o que estava diante dele. Inventar seria agora produzir uma dobra na imagem, desdobra-la.

As histórias, num mesmo filme, se multiplicavam e se permeavam. Os narradores também se tornavam vozes múltiplas. Os filmes buscavam histórias que não pareciam sair do prólogo. Pareciam repetir e recomeçar; repetir o recomeço. Muitas vezes esse recomeço era extremamente violento ( $O$ anjo nasceu e Câncer).
A imagem ela própria começava a oscilar, sair do prumo, deixar o tripé e fazer notar a câmera a construir histórias, personagens, espaço e tempos heterodoxos. As situaçôes pareciam cheias de buracos, desconexas. As ações e as situações em que se encontravam os personagens iam se tornando cada vez mais rarefeitas (Família do barulho). A câmera que deixava o tripé buscava sua própria independência em relação ao personagem. As trocas entre a câmera que produzia a imagem e a realidade que se imaginava eram aparentes ao espectador - uma vez que a câmera deixava perceber seu trabalho de captação aos olhos do espectador e os cortes da montagem eram cheios de saltos e descontinuidades. Tudo aparente, porém opaco. A reversibilidade entre narradores diversos - multiplicidade de vozes narrativas - fazia a subjetividade deslizar (Bandido da luz vermelha). A imagem-movimento perdia então a raiz que a matinha no interior da tradição do cinema. Ela buscava fugir e se conectar com outros campos. A imagemmovimento descobriu as ruas da cidade, a cultura urbana, a história em quadrinho, as imagens-clichês em seu complô contra o cinema (Copacabana me engana). O cinema já não era mais cinema sendo ainda cinema. Esse paradoxo perturbava o espectador que se via então obrigado a constituir pontes entre as imagens desconectadas, organizar o caos, inventar sentidos, criar o filme que não parecia pronto, mas que o atingia assim mesmo, violentamente. $\mathrm{O}$ espectador se via obrigado a ver algo que jamais vira; descobria a vida, como algo que flutua e se dispersa, mas que não se pode ver com os olhos do cotidiano. O cinema se tornava quase-cinema ao tocar essa vida.

A noção de filme mudava radicalmente. Agora não bastava questionar a narrativa tradicional como teria feito o Cinema Novo. Já não era suficiente perguntar o que é o cinema. Tratava-se de perguntar o que é a Arte. Qual a rea-

1 Ver o conceito de imagem-oscilação em Costa, 2000. 
lidade mesma da obra cinematográfica senão ser ou não ser arte? Onde a obra se realiza? Ela se realiza na tela no momento da projeção? Qual o papel do espectador? Bastava que ele olhasse uma realidade diante dele ou era preciso que ele mesmo a realizasse? O que significaria realizar a imagem que flutua? Era preciso inventar a realidade que insistia em se desfazer diante do espectador; era necessário produzir uma dobra naquela imagem desviante para que ela se fizesse real. Mas tornar uma imagem real era fazer uma imagem que por sua vez era também fugidia.

Com toda essa mudança que ocorria no cinema dos anos 70 - o desenraizamento da imagem-movimento de sua própria tradição e a vontade de buscar novos territórios -, a tendência seria que o cinema encontrasse questões mais gerais que envolviam as artes, a literatura, a música. A pergunta "o que é arte" passa a surgir no meio cinematográfico. Ela se tornava mais urgente do que a pergunta "o que é o cinema". Filme de amor, o trabalho mais recente de Júlio Bressane expressa toda essa transformação, com uma diferença: agora o que ocorre é uma transmissão da ruptura e do desvio. E já há uma história da ruptura que só pode ela mesma ser desviante. No movimento de sair do cinema e descobrir a questão "o que é e o que não é arte", o cinema se descobre quase-cinema, porque ele é também performance, pintura, teatro, poesia sonora. Filme de amor é, fundamentalmente, labirinto.

Pode-se considerar que Filme de amor tenha mesmo uma história, um entrecho, que torna o filme até acessível a um público menos inventivo. Duas mulheres e um rapaz, os três de classe média baixa, vindos de diferentes lugares da cidade do Rio de Janeiro - uma das moças usa o trem como transporte e o rapaz trafega em um ônibus -, se dirigem a um sobrado no centro da cidade, todos com um saco plástico de supermercado na mão. Neste sobrado, os três se embriagam, usam drogas, fazem leituras de trechos de clássicos da literatura como Moby Dick. Os três se encontram para um final de semana dedicado à imaginação e às experiências do desejo, dos prazeres do corpo e do espírito.
Depois retornam às suas vidas cotidianas: o rapaz corta cabelos, uma das moças faz unhas e a outra é ascensorista do mesmo prédio do salão em que os outros dois amigos trabalham.

Mas o filme só pode ser contado assim em um parágrafo porque todos os buracos, os vazios, os caminhos que se bifurcam foram preenchidos, ou melhor, eliminados. A diversidade de desvios que o filme faz pela literatura, pelo cinema, pelas artes é muito grande e o entrecho fica distendido por esses intervalos. Os personagens lêem textos de literatura enquanto seus corpos buscam as posturas do corpo equivalente ao que lêem. O filme se pergunta o que há entre a literatura e a performance, entre a literatura e o cinema, entre o cinema e a pintura. Bressane afirma no jornal de lançamento (maio de 2004):

"Filme de amor é sobre duas coisas: intervalos e sobrevivência. $O$ intervalo é o que está entre as imagens. A sobrevivência fala das pessoas movidas por um impulso inconsciente, um desejo de recriar a existência para poder sentir aquilo que é duro demais para sentirse, isto é, o sentimento de amor."

O espectador não pode facilmente seguir uma história. Há que se colocar nos intervalos para poder ver isso que é estranho ou terrível demais. Assim o espectador-participador deve fazer e refazer caminhos propostos pelo filme para uma recepção mais sofisticada. Mas essa participação não significa uma leitura mental, não envolve propriamente raciocínios lógicos. Diante de todo esse labirinto, diante de todos esse desvios que passam pelo Renascimento com o retorno às Três Graças de Boticelli, a pintura moderna de Balthus e as performances corporais e sonoras contemporâneas, o espectador tornase também um sobrevivente como os personagens do filme. O espectador é continuamente interpelado, convocado a participar antes como uma testemunha a quem se endereça, a quem se passa um testemunho. Ele não é apenas o juiz a quem se pede que determine o que é arte e o que não é. Ele é o testemunho de uma potên- 
cia. Filme de amor passa ao espectador o testemunho da possibilidade da arte contemporânea diante da história da arte desde o Renascimento. O espectador não olha como quem contempla uma realidade (arte da representação). Tampouco participa (arte política). Ele é testemunha porque pode ver algo ao lado de outro, através do olhar de outro, sendo ele mesmo.

Os jogos que os personagens se propõem são eles mesmos estranhos ao olhar comum, isto é, ao olhar que deseja ver à distância para comunicar o que viu. Mas a convocação ao testemunho propõe uma comunidade de troca. $\mathrm{O}$ espectador se perde ao buscar a situação narrativa. Ele esquece sua localização, seu espaço de espectador e entra nos jogos propostos, se sente embriagado, fascinado. As imagens o enganam, desviando -o por diversos caminhos muitas vezes não identificados. É preciso fazer conexôes, imaginar, buscar saídas. As pistas para as conexões e para os caminhos que os sentidos tomam vêem de mundos externos ao cinema. Não estão efetuadas, de fato, uma vez que são pistas. São jogos propostos pela instância narradora. Afinal, qual a relação entre o tema das Três graças com a baleia Mobi Dick? Para que essas transiçõos se realizem é preciso que elas sejam produzidas pelo espectador. É preciso que o espectador produza as dobras, pois o filme é antes a proposição de um filme. Inventar Filme de Amor é fazer leituras possíveis na passagem com a literatura, com as artes plásticas, com o teatro. É entrar num dos desvios convocados pelos trechos literários lidos, pelo som de um outro filme, pelas posturas dos corpos que remetem à história da pintura, pela sonoridade que nos leva à música dadaísta de barulho, à poesia sonora. O espectador oscila entre o participador - quando age mentalmente para produzir as conexões e realizar o filme - e o testemunho visionário quando cai nos intervalos e desvios do labirin- to. O filme ele mesmo pede para ser inventado, desdobrado, construído com os elementos dados. Por outro lado, Filme de amor impede as conexôes determinantes do raciocínio e exige que o espectador se torne um sobrevivente testemunho, como os personagens. O filme ele mesmo é antes a sombra de um filme que ainda não foi feito. O que ele apresenta é o intervalo onde o filme se encontra, um espaço virtual no qual o espectador precisa se colocar, ser também testemunho e sobreviver para desdobrar, recriar. O espectador, participador e testemunho, terá de inventar o filme, que é apenas um prólogo,uma proposta ao espectador que não pode mais ser apenas juiz. Ele agora fará parte da mesma comunidade que o artista-cineasta: a comunidade dos visionários, esses que podem ver algo estranho demais para a vida cotidiano.

É nesse sentido que Filme de amor coloca a questão da arte contemporânea: a obra como desdobramento de um mundo possível; o artista aquele que produz dobras em um mundo possível; o espectador, simultaneamente, participador e testemunha. $\mathrm{O}$ artista não produz significaçōes, mas valores que estão em devir. Júlio Bressane desdobra Balthus, Mobi Dick, a música barulho dos dadaístas, o seu próprio cinema e principalmente o mito das Três Graças. Esse é o movimento principal do Filme de amor: apropriar-se de alguma obra ou movimento da história da arte para desdobrá-los, indicar leituras, produzir valores que não passam de inflexões que exigem outras leituras.

Esse sentido de obra já estava implícito nos ready-mades de Duchamp. A obra não é o objeto que o espectador encontra diante de si, mas o desdobramento que é preciso produzir. É verdade que o desdobramento produzido por Duchamp e exigido ao espectador é antes de qualquer coisa um julgamento estético: "é arte" ou "não é arte". ${ }^{2}$ Mas um ready-made não é

2 Thierry de Duve coloca esse problema de uma nova modalidade de julgamento estético, "isto é arte" ou "Isto não é arte", numa releitura de Kant após os ready-mades de Duchamtp. De Duve também 
apenas algo que foi deslocado de um espaço não artístico para o lugar da arte. Um ready-made não só expõe a instituição e seus agenciamentos, ele indica a noção da obra como desdobramento. Fazer a leitura de um ready-made como objeto estético é perder o sentido daquele objeto, pois o sentido está fora dele ainda que nele persista. O sentido está na borda do objeto, por isso ele deve ser desdobrado. Deve-se encontrar novos limites para o objeto. Mas dobrar não é efetuar a realidade de um objeto como se pudéssemos ser sua causa. Dobrar é antes permitir que o efeito se produza. Não se pode entender um ready-made de Duchamp por suas formas sensíveis, é preciso ser captado por seu efeito. O efeito é o julgamento estético, uma decisão tomada pelo espectador, que já não é mais afirma "isto é belo" ou "não é belo". A obra é esse efeito. $\mathrm{O}$ efeito é o conceito de arte provocado pela presença do objeto. $\mathrm{O}$ que importa para Duchamp é a leitura produzida, o desdobramento efetuado pelo observador na relação com o objeto. É nesse sentido que ele afirma a indiferença diante do objeto. Ele dizia que o que o atraía na escolha de um ready-made não era um interesse plástico ou visual, mas a indiferença estética que permitia a produção de uma idéia, um conceito de arte (Siegel, 1992).

A obra para Bressane, como a de Duchamp, também não é mais um produto estético, mas a sombra, o fantasma de um mundo virtual que o próprio filme busca. Mas a operação de Bressane se diferencia já daquela de Duchamp, pois não passa apenas pelo julgamento de um objeto que pode se tornar arte deslocando-o para um lugar de arte. Sua operação é antes essa da sobrevivência, do desejo de recriar a existência para que se possa perceber algo que não se pode perceber com os olhos do cotidiano. É aí que o espectador passa da participação à testemunha. Ver não é mais ver na luz, mas ver na sombra deixada pela luz, ver na ausência mesma da luz. Ele diz continuamente que a imagem no cinema é sombra e mais uma vez ele repete no jornal de lançamento do filme:

"O que conta é o movimento da luz. O que age dramaticamente em cena é a luz, que ao distribuir sombras pelo cenário nos revela algo essencial do personagem e do instrumento sensível que nos fala desse personagem: a sua condição de sombra."

É claro que Bressane fala aqui sobre um aspecto do cinema que sempre deu muita importância: o cinema como música da luz. O que é fundamental no cinema para Júlio Bressane é a imagem-luz. A luz é a ordem primeira do cinema, ela é a ordem mesma do movimento. Mas as imagens só aparecem sob a condição de ser sombra. O cinema para Júlio Bressane nada tem a ver com uma realidade pré-existente. A imagem não é de modo algum isso que vem depois da realidade. Ela é ao contrário, o que vem primeiro, mas primeiro como sombra da luz. E a luz é movimento, traço, trajeto para fora, desvio. A realidade da imagem é, portanto, o engano, sua potência para o erro. A imagem no cinema de Bressane é um fantasma errante, sempre incapaz de se fixar. Ela erra pelas diversas dimensōes da cultura e da arte: a literatura, a pintura, o teatro, a música, o barulho, as posturas do corpo, a performance, etc. Ela parece estar em todos os lugares que são espaços quaisquer da arte e da cultura, da memória e do desejo.

O mito das Três Graças é central no filme de Bressane, afinal, o amor é esse sentimento que é preciso testemunhar mais que conhecer. $\mathrm{O}$ amor passa pelo desejo; diz respeito ao corpo e à carne. Duas cenas do filme dão a medida da importância do desejo e do afeto, do

repensa o espectador como testemunha, esse que não é mais apenas juiz, mas aquele a quem se endereça algo que é indizível (cf. Ferreira, 1998). Gilles Deleuze também coloca o problema do espectador como testemunho em Francis Bacon, lógica da sensação. 
corpo e da carne. Enquanto Hilda, uma das personagens femininas, lê ao telefone uma passagem literária que descreve gestos sensuais e posturas sexuais, Gaspar vai repetindo o que ouve ao lado de Hilda; "Apalpa minha cona, mete o dedo lá dentro para ver o que operava e não sabendo o que mais fazer, pôs-se a passear pelo quarto", diz a personagem feminina. Matilda está do outro lado da sala com outro telefone no ouvido, escutando as descrições da amiga que continua sua leitura apimentada, vendo-a refazer as posturas indicadas no texto.

"Então obrigou-me a pôr-me em posição numa cadeira e ajoelhou-se diante de mim, e a pomada fez com que entrasse um pouco mais. Levantou-me e obrigou-me a pôr-me de gatas em cima do leito. E tendo-se novamente esfregado com a pomada..."

O desejo é experimentado como todas as possibilidades do corpo, suas posturas libidinosas, suas atitudes pornográficas. Bressane aproveita para utilizar, como já teria feito em outros filmes como Tabu, algumas imagens de filmes pornográficos antigos. A carne também não é algo metafórico, mas o afeto encarnado. A carne remete à experiência da imagem na pintura, ao encarnado na imagem. E Filme de amor busca essa experiência da carne, com as texturas das paredes e a utilização da cor e do preto e branco na fotografia. $O$ corpo aparece nos gestos, nas posturas e atitudes do corpo, enquanto que a carne aparece como ordens do afeto, texturas e cores. Mas aqui o afeto é qualidade. Há uma outra ordem do afeto e da carne cuja experiência é pura potência: a montagem. A montagem afetiva desfaz a ordem espacial do imóvel onde os três personagens experimentam seus desejos inconscientes, seus afetos incomuns, seus pensamentos impensados. A montagem apresenta um espaço que é pura potência e um tempo que é virtual, pois o presente parece se desatualizar nos textos lidos, nas posturas vividas como no momento em que os três personagens começam a levitar e flutuar pelo espaço do sobrado. A montagem como experiência artístico-cinematográfica passa pela ordem afetiva, como potência que encarna um pensamento que flutua.

A importância e centralidade do tema do amor estão indicadas no próprio título. Mas o amor é o assunto que conjuga os outros interesses do filme. Todos os temas, mesmo o amor, aparecem como alguma coisa a que se está rodeando, se acercando, que já se conhece e ainda não se conhece. Isso não significa que Bressane não tenha pesquisado o suficiente seu objeto. É que esse objeto não pode ser determinado pelo filme, senão ele é automaticamente perdido. A primeira sensação que o espectador tem é que o filme não diz algo muito importante ou especial sobre as Três Graças ou sobre o amor, uma vez que ele não pode determinar isso que se diz e o que se mostra. É como se ele visse no escuro e ouvisse por entre ruídos. Com isso o filme produz afetos múltiplos e errantes sobre o tema. O filme começa com três figuras à beira mar, duas mulheres e um homem. São imagens que já investigam as posturas e atitudes do corpo: de pé contra o céu e contra um morro, deitados sobre a pedra à beira mar; os pés de uma mulher que caminha sobre as águas. Segundo conta a mitologia, Afrodite - para os gregos ou Vênus, para os latinos - nasceu da espuma do mar perto de Chipre. Assim o filme, desde o início, se coloca como que à espreita para que esse acontecimento possa se efetuar ali com aqueles personagens. $\mathrm{O}$ filme busca, cerca, circunda, gira em torno desse acontecimento que ele mesmo espera mais que determina ou relata e do qual o espectador será testemunha.

Essa seqüência da praia não é de fato a primeira. Antes dela há uma outra em que a equipe da produção é mostrada em cenário interior e em preto e branco que tem a função de aludir ao fazer artístico, ou melhor, à competência exterior que é a instância narradora. A narração do Filme de Amor, porém, não conta uma história, ela narra o processo de ir e vir, a sucessão dos estados e mudanças, o curso dos retornos e desvios desse acontecimento que é o Amor. Em um texto importante de Maurice 
Blanchot, "Falar não é ver", o escritor francês parece descrever esse movimento da busca e dos desvios que encontramos no filme de Júlio Bressane:

"Encontrar, buscar, girar, ir em volta: sim, são palavras indicando movimentos, mas sempre circulares. Como se o sentido da busca fosse necessariamente um giro. Encontrar inscrevese nesta grande "abóboda" celeste que nos deu os primeiros modelos do movediço imóvel. Encontrar é buscar em relação ao centro, que é ele próprio inencontrável" (Blanchot, 2001).

Esse é o sentido de mostrar a equipe filmando: mostrar que eles estão nessa busca do filme. Mas buscar o tema ou o filme não é dizer "está aqui", não é determinar um espaço e um tempo em que algo acontece. É antes abrir todos os espaços e todos os tempos, criar intervalos onde se possa passar muitos tempos, do desejo e da memória, do futuro e do passado.

Nesses vários desvios do tema central há um interesse que é indicado por um letreiro sobre um muro: "Mulher!". Como entender um homem entre duas mulheres quando o tema é o mito das Três graças? O homem aqui já não é o padrão, o que não significa dizer que ele é homosexual, como as mulheres chegam a cogitar no filme. O homem é esse estado de mudanças experimentado pelo filme em direção à mulher. A equipe do filme mostrada no início é dirigida por um homem, e fazer um filme que reinvente as Três Graças é refazer o mito dessa trindade onde uma das três seja uma figura masculina. Já não é mais uma visão do feminino representada por um homem, mas a visão do feminino como aquilo que falta ao homem para ser homem. Mostrar a equipe não é somente para dizer que esse é um discurso masculino e todos os sentidos poderão ser remetidos a essa instância formadora e responsável pelo discurso. Mostrar a equipe é antes afirmar que o desvio é necessário ao discurso para que ele não seja mero dispositivo de afirmação do poder e do padrão. Assim funciona a placa "popular" que se pode ver do lado de fora do prédio para onde os três personagens se dirigem no início do filme. Esse letreiro indica essa vontade de ultrapassar a borda, tocar o limite do outro, para se colocar ao seu lado, junto ao outro. Já não se trata mais de falar pelo outro, mas de colocar-se junto àquele que lhe é estranho e descobrir tudo aquilo que não se tem para que se possa se outro.

"Então esse é o novo equilíbrio, o novo valor desse triângulo, dessa trindade: que uma das graças possa ser uma graça masculina, o que quebraria, no momento do nascimento dele, o encanto. Justamente, devido ao que faltava ao masculino e que você podia acrescentar à mulher que não existia naquele. Existia a visão do masculino sobre como deveria ser o feminino. Então a própria Três Graças é uma visão masculina, mas hoje se impôs a essa, se impôs pelo menos a mim, a compreensão desses valores e desse equilíbrio queira você ou não, porque o equilíbrio vai existir antes de você, porque é uma trindade. O valor masculino, agora o valor masculino, com essa masculinidade transformada."

A fala popular do filme é antes o limite de uma fala culta. É uma fala culta que gagueja. Não há mais propriamente diálogos ou conversas no filme. Há falas indiretas livres ${ }^{4}$. São todas falas em que há sempre um outro, seja Augusto dos Anjos ou o historiador da arte Aby Warbur. A fala encontrou aquilo que lhe faltava para que pudesse ser culta, se colocou ao lado do homem

3 Júlio Bressane, em entrevista não publicada dada ao autor deste artigo.

4 Gilles Deleuze aponta para esse problema, a fala do cinema se transforma e se torna discurso indireto livre. Cf. Deleuze, 1990. 
popular e tornou-se estranha, misteriosa, múltipla. Filme de amor não é culto nem popular. Se ler trechos de Mobi Dick é considerado culto, o que dizer da ação de fritar bifes e ovos em ferro quente? A linha que separa a cultura letrada da não letrada, em Filme de amor, o masculino do feminino, a arte da não arte é o tema do filme. O limite que aparece e desaparece sem que notemos é precisamente o que afirma o filme, a flutuação e o engano como valores.

O problema do limite não se resume ao gênero artístico, sexual ou social. Afinal o que nos faz ser humano? Qual a condição para que sejamos humanos? O filme faz referência a muitos animais: o rinoceronte, o crocodilo, o jacaré, a baleia (Moby Dick), o cavalo (a estátua do cavaleiro em seu cavalo no final do filme), o gato que jamais aparece e o morcego. Qual poderia ser assim o interesse do filme em relação aos animais? E onde está esse gato do qual ouvimos os miados, mas que, como a personagem Hilda, não vemos? Hilda procura o gato, deixa o leite em sua vasilha, o leite desaparece, mas nunca o vemos. É claro que cada um desses animais surge em contextos distintos no filme. $\mathrm{O}$ morcego surge quando Matilda fala da lua, uma imagem que remete ao olhar do morcego.

Nessa altura do filme, os três personagens já haviam bebido, fumado, cheirado algum vapor inebriante de um lenço, e entrado em conversas sobre a beleza e também a lua. "Entre a lua e cada um de nós existe um fluxo, um movimento de força, de vida. A vida de cada um de nós depende da lua", diz a personagem Matilda. Ela continua, agora olhando para o alto onde se situa a câmera:

"E a lua depende de cada um de nós. Mas de que maneira, cada um de nós depende da lua? A lua é a mãe da escuridão. Ela é a pista, o indício, para a escuridão ativa. E nós, abaixo da cintura, nós temos o nosso ser na escuri- dão. Abaixo da cintura nós somos sem visão. Abaixo da cintura nós somos sem visão. É fácil ver, por que cada homem mata aquilo que ama. Conhecer uma coisa viva é matá-la. É preciso matar a coisa, para conhecê-la satisfatoriamente. Por essa razão, a consciência desejante, o espírito, é um vampiro.”

A câmera que vê Matilda é uma câmera alta. Quando Matilda termina sua fala, a câmera desce, gira e mostra Gaspar e Hilda de pé, um de costas para o outro, ambos de cabeça para baixo. É uma câmera-morcego. No início da fala a câmera alta não tem subjetividade diegética, isto é, não é o olhar subjetivo de nenhum personagem. Poderíamos dizer que é objetiva, embora isso signifique o ponto de vista de uma subjetividade que é o da instância narrativa. Ainda que a câmera se faça notar, esse ponto de vista alto é aceito sem problemas pelo espectador, uma vez que a personagem tem seu olhar direcionado para a lua sobre a qual fala. Há motivação diegética para tal posicionamento de câmera. O espectador então aceita o ponto de vista como índice da existência da lua acima do olhar da personagem e para a qual ela olha. No entanto, assim que Matilda termina seu discurso dizendo a palavra "vampiro", a câmera parece tomar vida ou mesmo dar vida a outra subjetividade no interior da cena que já não é a do narrador-câmera. Agora esse narrador parece adquirir uma vida não humana, uma vida vampiresca. É o cinema contemporâneo desejando falar não mais com metáforas ou alegorias. Esse cinema quer concretizar novas subjetividades: esse que conta ou inventa seus personagens se inventa a si próprio ao inventá-los. A subjetividade em Filme de amor é fundamentalmente dupla, ou melhor, a percepção é indireta livre e produz um novo homem, formado por aquilo que lhe falta para ser homem: seu devir mulher, seu devir animal. ${ }^{5}$

5 A tese de uma subjetiva indireta livre é incialmente proposta por Pasolini em Empirismo Hererje, partindo de Mikhail Baktin (Pasolini, 1982). No Brasil, essa discussão foi recolocada por Ismail Xavier, 
A instância narrativa então aparece criando seus personagens e ao mesmo tempo se criando. A criação não é mais algo misterioso, pois o "fazer fílmico" tornou-se transparente ao espectador? O problema deve ser colocado de modo diferente. Bressane coloca na boca de seus personagens frases de poetas e filósofos. Há citações lidas diretamente de livros e outras apropriações que não são indicadas como citações. A certa altura do filme, Gaspar diz:

"Escuto. E vejo. O que é que eu vejo? Eu vejo Recife. Ponte Buarque de Macedo.

$\mathrm{Eu}$, indo em direção à casa do Agra.

Assombrado com a minha sombra magra,

Pensava no Destino e tinha medo!

Lembro-me bem. A ponte era comprida.

Minha sombra enorme enchia a ponte."

Aqui Bressane colocou na boca de seu personagem Gaspar algumas palavras do poema "As cimas do Destino". O poema de Augusto dos Anjos começa com o verso aqui iniciado com a palavra "Recife". Os dois últimos versos que Gaspar fala não dão continuidade, no poema original, à primeira estrofe como aqui. Esses dois versos iniciam a terceira estrofe no poema de Augusto dos Anjos. Bressane, inescrupulosamente, se serve das palavras do poeta, mas recorta e recompóes o poema, além de não identificar o poeta, ainda que o homenageie. $\mathrm{O}$ trabalho da recepção como o da criação identificando ou não tal colagem, é fundamentalmente desdobramento. Mas desdobrar não é simplesmente citar ou apropriar-se de obras ou partes de obras. Desdobrar é inventar essas obras de um ponto de vista contemporâneo; é transmitir essas obras com o olhar da ruptura. Assim trabalha Bressane em Filme de Amor, dobrando e desdobrando autores, pintores, músicos, agenciando-os todos em uma grande comunidade labiríntica, uma rede de sentidos que se produzem entre diversos meios, entre diversos artistas, filósofos e historiadores da arte.

Em vários de seus textos, Bressane insiste na noção de "tradução intersemiótica", como transposição de uma linguagem para outra. Essa noção se transforma, toma novos nomes, se complexifica. Em seu livro Alguns trata dessas passagens entre meios em quase todo os artigos. No texto "Vieira e sua sombra", diz:

"E a tradução? E os Sermões-cinema?

Lembremos que em Vieira a imagem e o pensamento encontram em um mesmo plano.

Em sua vegetação de significações diversas desdobramos assim a imensa sombra do Sermões. Desdobramentos que nos permitem mapear o signo Vieira, para depois, e a partir daí, criar a imagem ou uma imagem que de alguma maneira nos remeta ao universo dos Sermões e espelhe alguma coisa de sua linhagem, de sua forma, de sua beleza.

1. Sermões-Música

2. Sermões-Pintura

3. Sermões-Cinema” (Bressane, 1996).

As noções de obra e de criação para Bressane são bastante particulares. A criação não diz respeito à produção de algo absolutamente novo, mas algo que pode ser desdobrado. Nesse sentido, a obra é uma sombra e o que ela cria é

que pensa o problema do dialogismo de Baktin e Pasolini e o aproxima ao monólogo interiror proposto por Eisenstein. Xavier rejeita, entretanto, o autor no lugar da enunciação do discurso dialógico para substituí-lo pelo narrador interno ao próprio discurso (Xavier, 1993). Deleuze propõe uma diferenciação entre o monólogo interior como sendo uma ordem proveniente de um sujeito, mesmo que inconsciente, e a subjetiva indireta livre, uma percepção dialógica em que estão envolvidas duas subjetividades (Deleuze, 1985). André Parente voltou ao tema em seu livro Narrativa e Modernidade e desenvolve a tese deleuziana de que o monólogo interior foi substituído pela subjetiva indireta livre no cinema moderno, com a diferença de que ele aceita a narrativização como um processo inerente à imagem (Parente, 2000, p. 56-83). 
uma relação com alguma obra anterior, um desdobramento que "espelhe alguma coisa de sua linhagem, de sua forma, de sua beleza”. Bressane procede com as obras da cultura e história da arte de modo semelhante com que Duchamp procedia com os objetos do cotidiano. Bressane retira esses objetos que parecem envelhecidos e empoeirados pela cultura que os valorizou, mas não pode mais perceber seu valor, sua diferença artístico-poética. Bressane dobra esses objetos para dar-lhes novo valor. Mas esse valor não é uma significação. Esse valor é antes um vazio a ser produzido, um intervalo a ser criado, uma dobra a ser constituída. As palavras de Augusto dos Anjos não são explicadas. Ao contrário, são mantidas vagas, tornadas novamente misteriosas, como a sombra magra do poeta que caminha à casa do Agra, casa funerária de Recife. Porque Gaspar fala essas palavras? Qual a relação dele com Recife? Por que fala na morte, no destino de todo homem no momento em que experimenta os limites da vida?

Importante é notar que a noção de cinema mudou. $\mathrm{O}$ cinema não mais coloca seu personagem a fazer alguma coisa diante de uma situação de dificuldade. O cinema produz relaçôes com outros meios, outros territórios e nessas passagens descobre a vida e a morte, a arte e a não arte. É produzindo esse tipo de relação transmediadora com Herman Melville - autor de Mobi Dick - que Bressane encontra o cinema de John Houston e a arte sem gênero da performance-instalação. O tema do mar volta com a leitura do clássico de Melville na voz de Hilda, que menciona os três arpoadores e a caçada da baleia. Hilda termina por afirmar que Mobi Dick é a 'condenação da América do norte". A câmera se movimenta para a direita e mostra a baleia branca formada pelo lenço preso à porta de um armário e atado ao corpo de Matilda. Hilda continua sua fala em língua inglesa e logo ouvimos o som de voz masculina de uma cena do filme de John Houston.

Mas se há performances, há também poesias sonoras. A trilha toda poderia ser entendida como um longo poema sonoro. A começar pelo som do mar no início, seguido dos barulhos do trem. Mas há duas cenas especialmente interessantes nesse sentido, verdadeiros ready-mades sonoros. Em uma dessas cenas, Gaspar, vestido com um avental branco e um turbante na cabeça, segurando uma vassoura, vai até Matilda que está no sofá. Ela acorda e vê o homem diante dela que lhe dá a vassoura. Ela pega o objeto e começa a varrer o chão sonoramente e, numa coreografia, dança e rebola de calcinha. Um pouco mais à frente no filme ouviremos um diálogo bastante estranho e erótico, originalmente de $O$ rei do baralho, do próprio Bressane. E quando termina o diálogo, ouvimos o latido de um cão (no som inserido, a mulher e o homem terminam falando de cachorro), logo, um motor de um aeroplano e um estranho som retirado de cordas de algum instrumento. É Hilda que retira essas sonoridades estranhas de uma viola, puxando as corda e torcendo as chaves de afinação.

$\mathrm{O}$ filme termina com imagens de casais populares nas ruas do Rio de Janeiro. Mas dizer que o filme termina é mais um engano em que nos coloca Julio Bressane. A projeção termina, mas o filme é interminável. Antropofagicamente, Bressane devora a cultura trans-nacional e dobra a História da arte desde o Renascimento, passando pelos modernos para chegar à contemporaneidade nas artes. Nessa história cheia de intervalos e desvios, Julio Bressane aponta para um novo caminho, um último desdobramento de Duchamp,que já estava implícito nas experiências de Hélio Oiticica e Ligia Clark. Não basta que o espectador seja juiz, é preciso que ele seja também testemunha de um acontecimento e que produza com o artista uma comunidade. Essa é a potência da arte contemporânea: produzir territórios em que se agenciam interesses, em que se criam coletivos. Uma comunidade, porém, onde não se comungam as mesmas idéias, onde não se comunica algo determinado, mas uma comunidade com a qual se testemunha a experiência do desvio e do engano. É o cinema se tornando um quase-vídeo, o que Bressane já havia mostrado em Nietzsche em Turin.. 


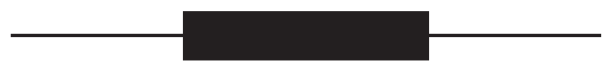

\section{Referências bibliográficas}

BLANCHOT, Maurice. A conversa infinita. São Paulo: Escuta, 2001.

BRESSANE, Julio. Alguns. Rio de Janeiro: Imago, 1996.

CANONGIA, Lígia. Quase-cinema, cinema de artista no Brasil, 1970-1980. Rio de Janeiro: Funarte, 1981.

COSTA, Cláudio da. Cinema brasileiro (anos 60-70): dissimetria, oscilação e simulacro. Rio de Janeiro: 7letras, 2000.

DELEUZE, Gilles. Francis Bacon, lógica da sensação. Paris: Éditions de la Difference, s.d. . Cinema 1: A imagem-movimento. São Paulo: Brasiliense, 1985.

. Os componentes da imagem. A imagem-tempo. São Paulo: Brasiliense, 1990.

FERREIRA, Glória. VENANCIO FILHO, Paulo (org.). Arte \& ensaios, n. 5. Rio de Janeiro: Revista do Mestrado em História da Arte/Escola de Belas Artes, UFRJ, 1998.

KAPROW, Allan. "O legado de Jackson Pollock”. In: O Percevejo. Revista de teatro, crítica e estética, Ano 7, n. 7, Rio de Janeiro: UNIRIO, 1999.

PARENTE, André. Narrativa e Modernidade: os cinemas não narrativos do pós-guerra. Campinas: Papirus, 2000.

PASOLINI, Pier Paolo. Empirismo Hereje. Lisboa: Assírio e Alvim, 1982.

SIEGEL, Jeanne. Artwords: discourse on the 60's and 70's. Nova York: Da Cabo Press, 1992.

XAVIER, Ismail. Alegorias do Subdesenvolvimento: Cinema Novo, Tropicalismo, Cinema Marginal. São Paulo: Brasiliense, 1993. 